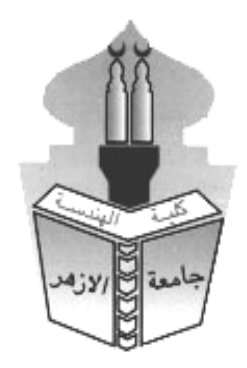

\title{
RELATIONSHIP BETWEEN EXCAVATION DEPTH AND DAMAGED ROCK ZONE FOR LOW STRENGTH ROCKS
}

\author{
M. E. Hassan ${ }^{1}$, W. M. Draz ${ }^{1}$, F. A. Ali ${ }^{1}$, S. M. Sleem ${ }^{1}$ \\ ${ }^{1}$ Mining and Pet. Eng. Dept., Faculty of Engineering, Al -Azhar University, Naser City, Cairo, Egypt
}

Received: 10 August 2021 Accepted: 1 September 2021

\begin{abstract}
The induced stresses around the excavation boundary cause a zone where the rock is physically damaged (mechanical properties are permanently affected), this zone is generally known as the Damage Rock Zone. Damaged rock zone (DRZ) has a significant effect on the stability of the excavation. Any problems associated with the DRZ create unsafe working environments and increase construction and supporting costs. In this paper, a simulation study for the Damaged Rock Zone (DRZ) around mine excavations at different depths $(100 \mathrm{~m}, 200 \mathrm{~m}$ and $400 \mathrm{~m})$ with disturbance factor $(\mathrm{D}=0,0.5$ and 0.8$)$ based on the experimental work with applying two software's (Roclab and Examine 2D). To accomplish this study, cylindrical core specimens of low strength rock (sandstone) was prepared. The core specimens tested using tri-axial compression machine at different confining stress levels from 1 to $12 \mathrm{MPa}$ in order to investigate their mechanical properties. The results introduced to the Roclab software to determine DRZ strength parameters, based on Hoek-Brown failure criterion. Finally applying Examine2D software to determine DRZ thickness. The results proved that, the extent of DRZ affected by depth of the excavation, with increasing the excavation depth, the DRZ extent increase.
\end{abstract}

Keywords :Damaged Rock Zone; Excavation Depth; Disturbance factor.

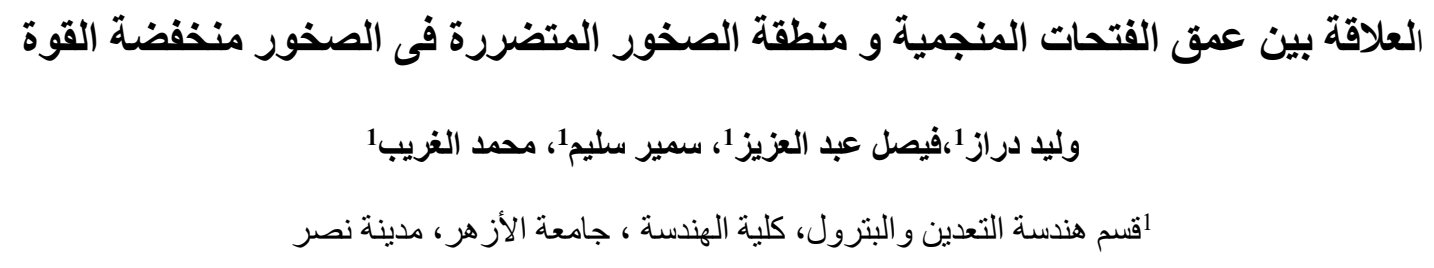




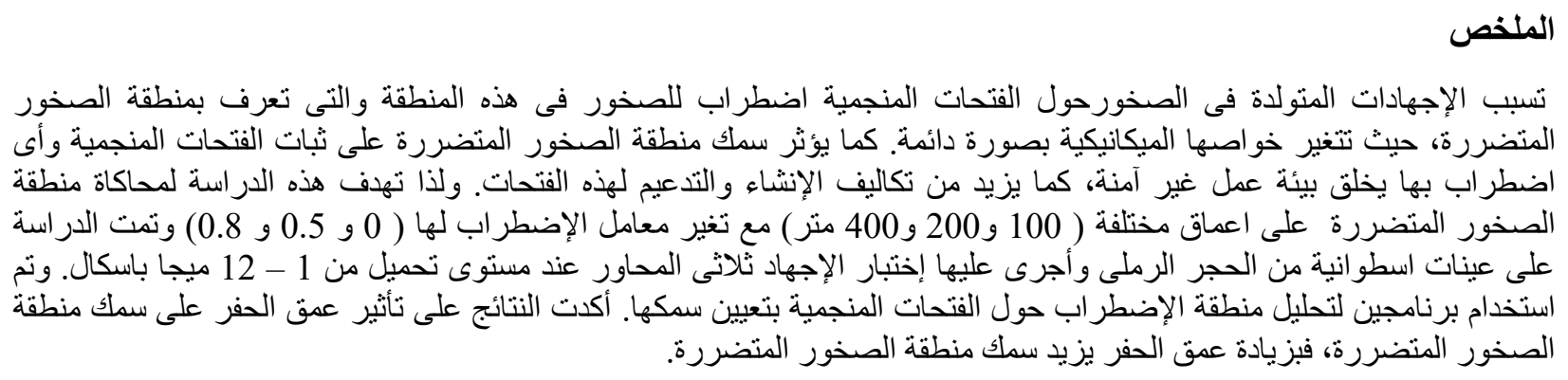

\section{INTRODUCTION}

The presence of a damaged rock zone (DRZ) around a tunnel boundary can significantly influence the overall performance of the tunnel. This zone although finite in extent, is thought to be responsible for problems relating to; over break resulting in removal of additional material and uneven tunnel profile, reduced confinement due to low stiffness, reduced rock strength, increased fracture intensity leading to free inflow and outflow of water, and effects on long term stability. Any problems associated with the DRZ can create unsafe working environments and increase construction and maintenance costs [1].

The excavation damage zone (EDZ) has been investigated worldwide, especially by the nuclear waste repository agencies and reported in many works, for example, [2,3,4 and 5].

The damaged rock zone is the closest zone to underground opening, that has suffered irreversible deformation and in which shearing of existing fractures, as well as propagation or development of new fractures has occurred. Spalling, with blocks/slabs detached completely from the rock mass, will only occur in high-stress situations, whereas damage and disturbance will occur due to the creation of the underground opening. Where disturbed zone is a zone dominated by change of state (e.g., stress, hydraulic head). The changes in rock mass properties are insignificant or reversible [6].

The authors studied the effect of rock type on damaged rock zone around underground excavation and the study proved that, the extent of (DRZ) varies depending on rock type. For a very good and strong rock this zone was small, whereas for weak rocks it was large. Also, the effect of Geological Strength Index (GSI) and disturbance result from excavation method used (Drilling and Blasting or Tunnel Boring Machine) on the extent of (DRZ) around excavations in many types of rocks [7].

In this study we examine the intact rock samples (sandstone as a low strength rock), then analysis the obtained values by Roclab software and estimate the strength parameters for DRZ, the output data introduced to Examine2D software to determine the Damaged Rock Zone thickness for rock mass.

\section{EXPERIMENTAL WORK}

The experimental work includes uniaxial and tri-axial compression tests carried out on sandstone, as an example for low strength rocks, to investigation of their mechanical properties as cylindrical samples with a height to diameter ratio $2(5.4 \mathrm{~cm}$ diameter and $10.8 \mathrm{~cm}$ height $)$. The tri-axial compression tests were carried out at selected confining pressure $(\sigma 3)$ ranging from 1 to $12 \mathrm{MPa}$. After analysis of data obtained from the laboratory tests for the studied rocks in Roclab software to estimate the strength parameters for DRZ, the output data introduced to Examine2D software to determine the Damaged Rock Zone thickness, the regions of overstresses around the underground excavations based on the generalized Hoek Brown failure criterion $(2002,2006)$ [8 and 9].

The excavation used in this study is circular with $10.8 \mathrm{~m}$ in diameter at depth $100 \mathrm{~m}, 200 \mathrm{~m}$ and $400 \mathrm{~m}$. The relation between disturbance and excavation method was used. The disturbance resulting from the excavation method used (Drilling and Blasting or Tunnel Boring Machine) is representing by an important parameter called Disturbance factor (D). The value of disturbance factor ranges from upper limit, base case and lower limit $(\mathrm{D}=0,0.5$ and 0.8$)$ respectively. 


\section{RESULTS AND DISCUSSION}

\subsection{Results}

After applying the tri-axial compression tests on sandstone samples, the results obtained represented in figure (1).

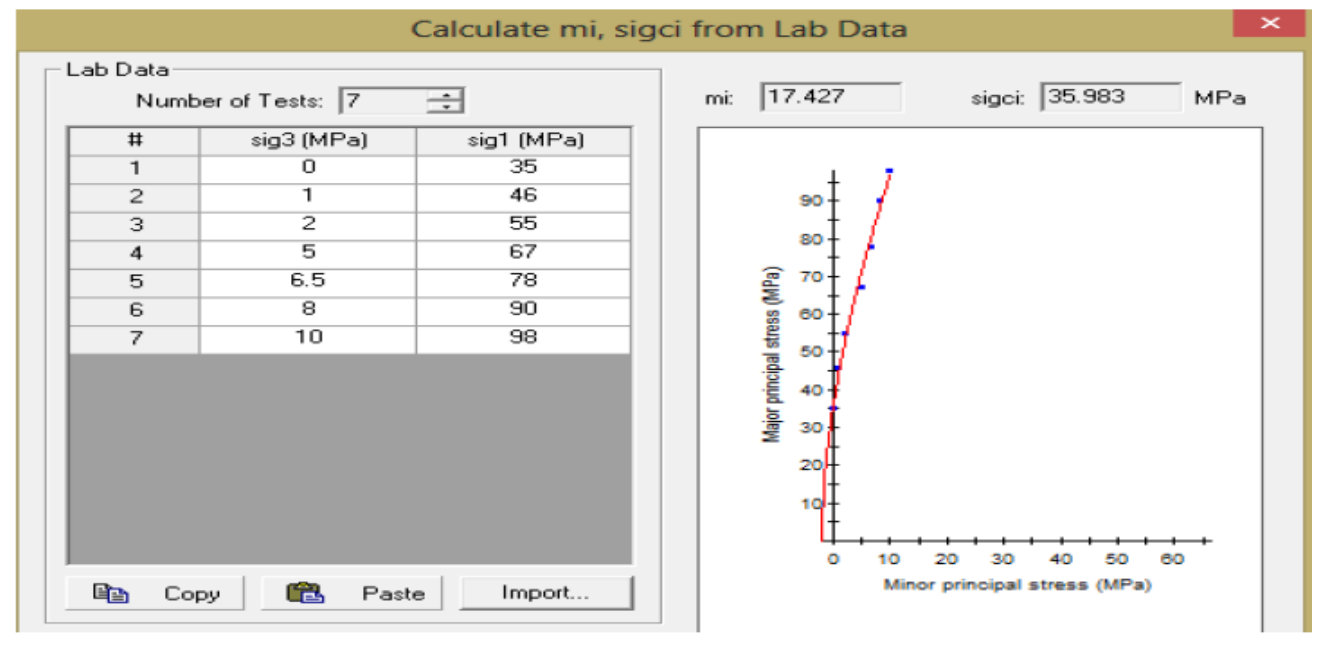

Fig. 1: Tri-axial test results for Sandstone samples.

\subsection{Estimating The Strength Parameters For Drz}

By applying Roclab software to determine the strength parameters of rock mass $\mathrm{m}_{\mathrm{b}}, \mathrm{s}, \mathrm{a}$, compressive strength of rock mass $\sigma_{\mathrm{cm}}$, intact rock parameter $\mathrm{m}_{\mathrm{i}}$, geological strength parameter GSI , rock mass deformation modulus $\mathrm{E}_{\mathrm{rm}}$, and deformation modulus of disturbed zone $\mathrm{E}_{\mathrm{d}}$. then applying Examine2D software to determine the damage rock zone thickness and its strength factor (strength/stress).

\subsubsection{DRZ Values at Depth $=100 \mathrm{~m}$}

\section{Upper limit (no damage)}

The upper strength is equal to the virgin or undamaged rock mass compressive strength $\sigma_{\mathrm{cm}}$, obtained directly from use of Hoek-Brown from the undamaged rock and $\left(E_{d}=E_{r m}\right)$. The disturbance factor (D) is zero. 


\section{STRENGTH ROCKS}

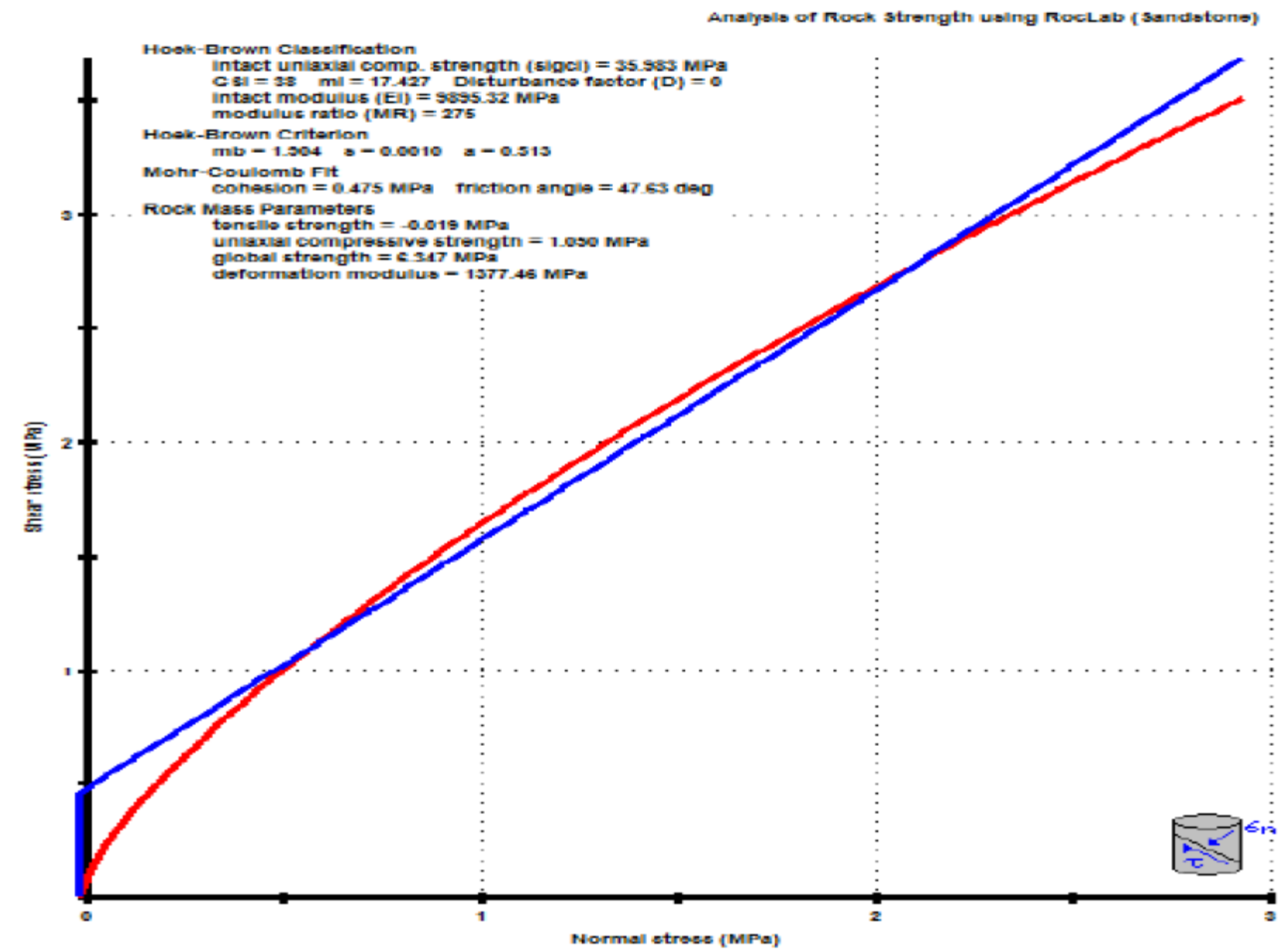

Fig. 2: Analysis of rock strength parameters by Roclab software at depth $=100 \mathrm{~m}$ and $D=0$.

The strength parameters of rock mass obtained from the Roclab software introduced into Examine2D software to Analysis of DRZ around the excavation boundary as shown in figure (3). 


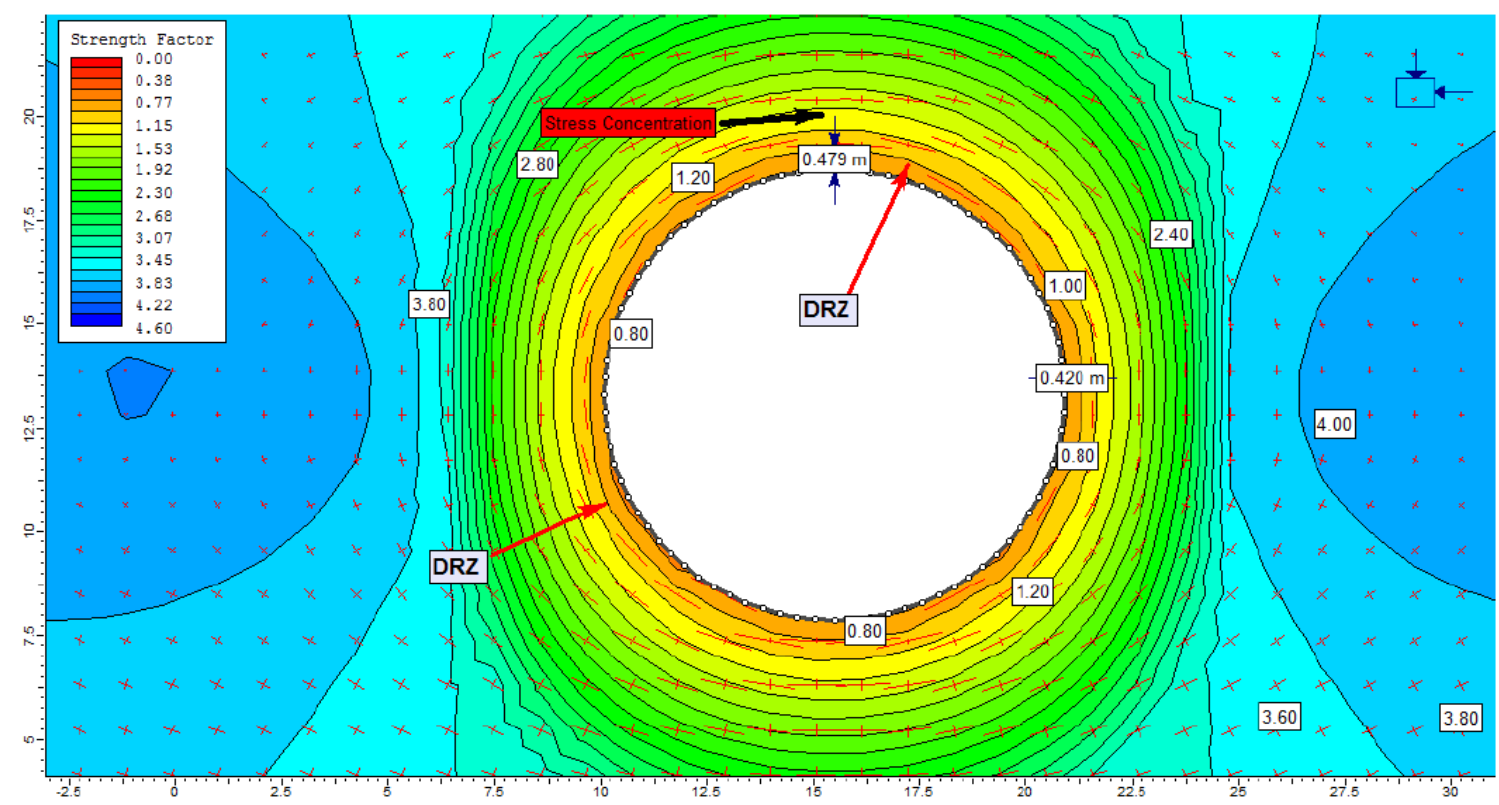

Fig. 3: Analysis of DRZ by Examine2D software at depth $=100 \mathrm{~m}$ and $D=0$.

\section{Base Case (DRZ)}

The Base Case of the disturbance factor $(\mathrm{D}=0.5)$. The corresponding reduction in the deformation modulus is by $51 \%$ (i.e. $\mathrm{E}_{\mathrm{d}}=0.49 \mathrm{E}_{\mathrm{rm}}$ ).

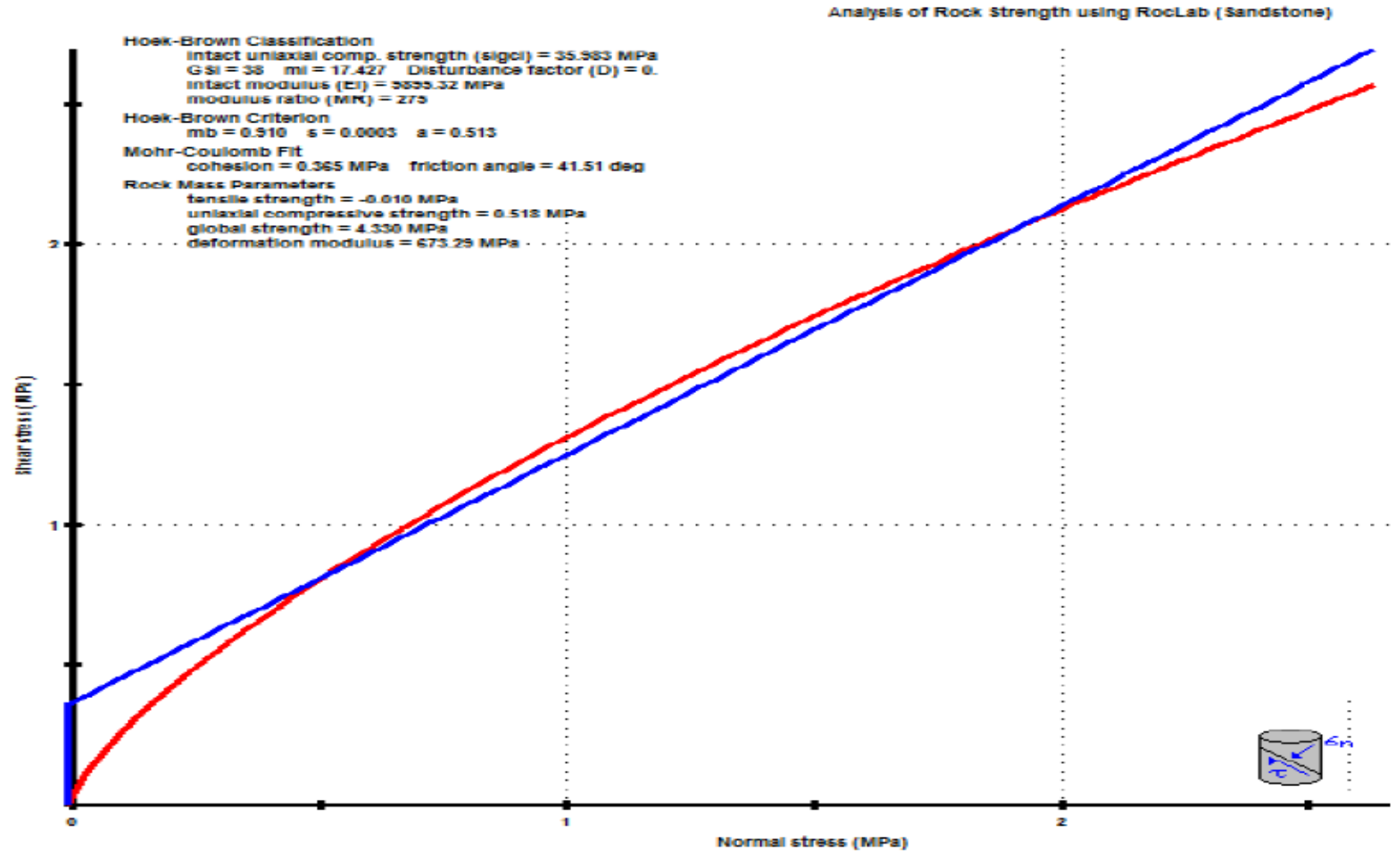

Fig. 4: Analysis of rock strength parameters by Roclab software at depth $=100 \mathrm{~m}$ and $D=0.5$. 


\section{STRENGTH ROCKS}

The strength parameters for rock mass obtained from the Roclab software introduced into Examine2D software to Analysis of DRZ around the excavation boundary as shown in figure (5).

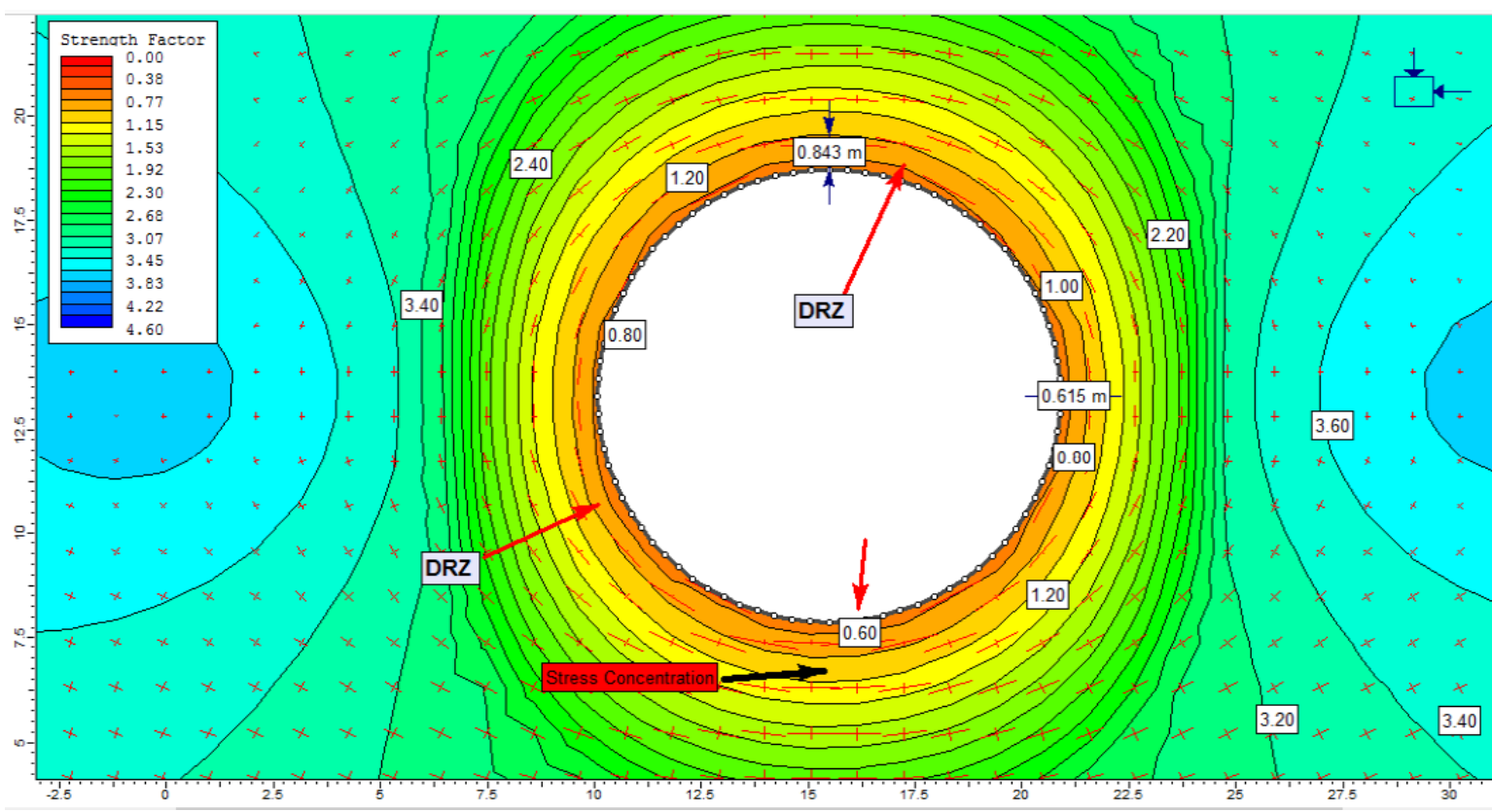

Fig. 5: Analysis of DRZ by Examine2D software at depth $=100 \mathrm{~m}$ and $D=0.5$.

\section{Lower Limit (Heavy Damage or Worst Case)}

This case occurs when the maximum disturbance factor $(\mathrm{D}=0.8)$ and deformation modulus being reduced by $67 \%\left(\mathrm{E}_{\mathrm{d}}=0.33 \mathrm{E}_{\mathrm{rm}}\right)$. 


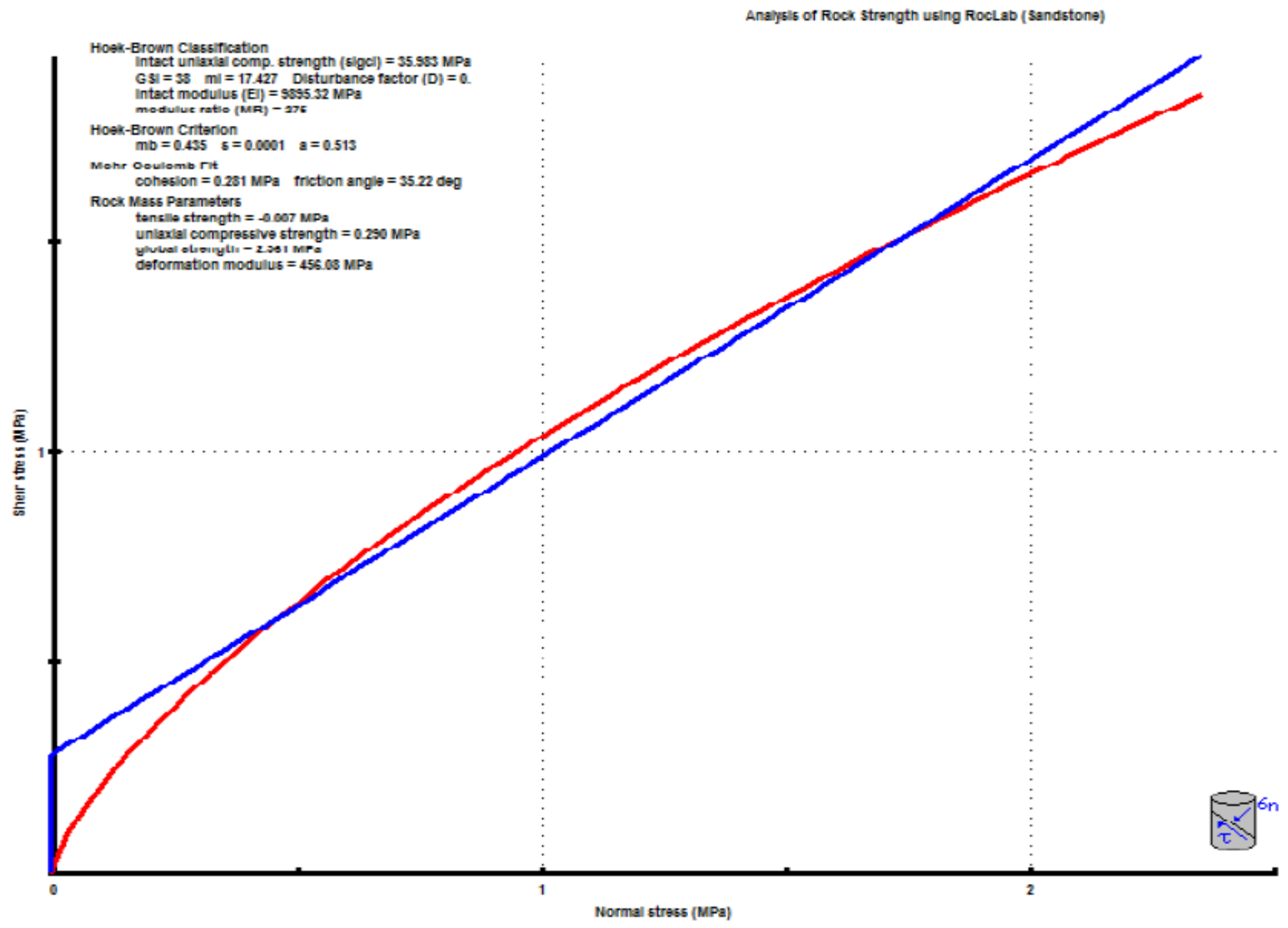

Fig. 6: Analysis of rock strength parameters by Roclab software at depth $=100 \mathrm{~m}$ and $D=0.8$.

The strength parameters for rock mass obtained from the Roclab software introduced into Examine2D software to Analysis of DRZ around the excavation boundary as shown in figure (7). 


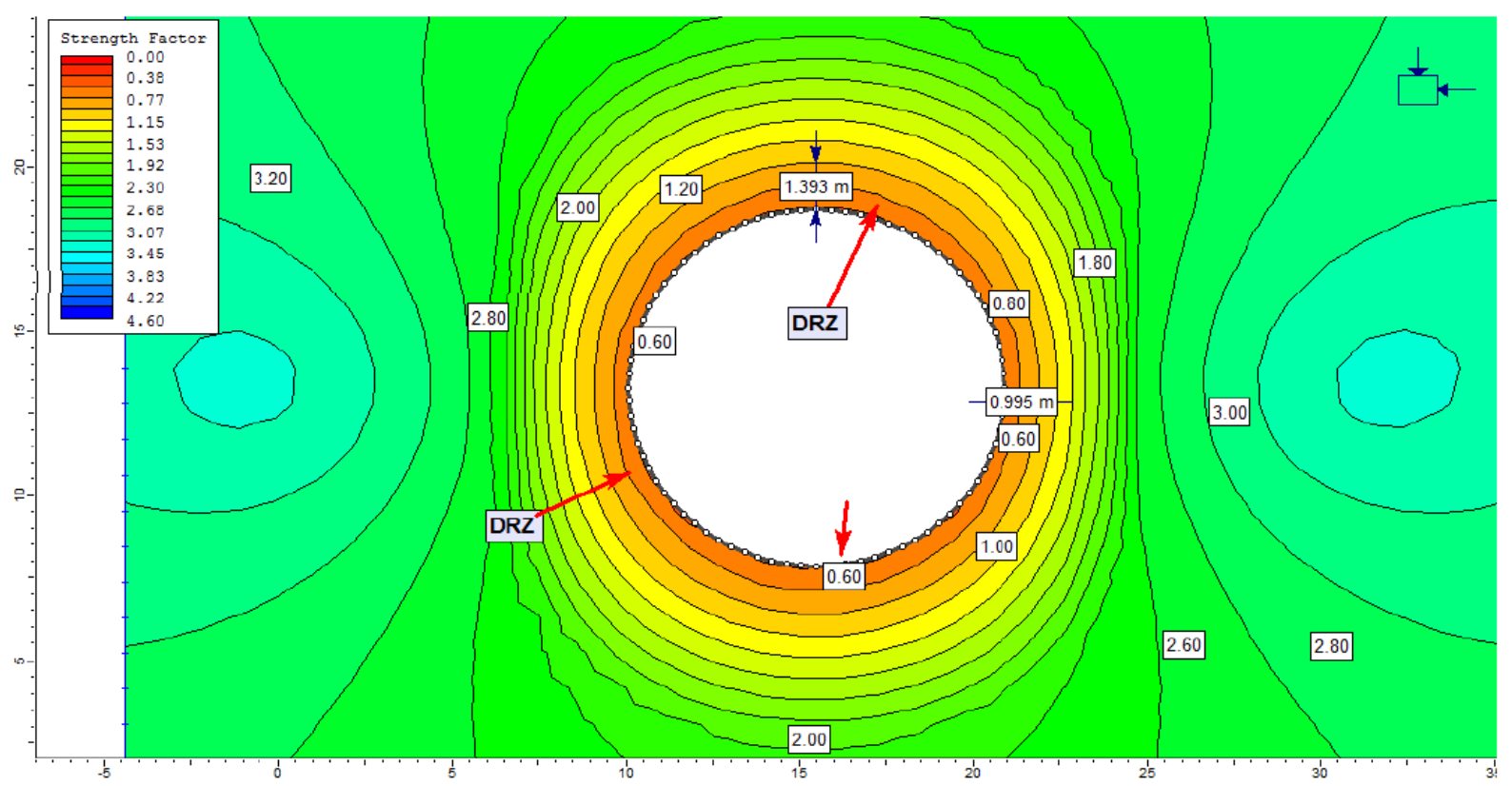

Fig. 7: Analysis of DRZ by Examine2D software at depth $=100 \mathrm{~m}$ and $D=0.8$.

\subsubsection{DRZ Values at Depth $=200 \mathrm{~m}$}

Similarly, by increasing the excavation depth to $200 \mathrm{~m}$ and $\mathrm{D}=0,0.5$ and 0.8 as shown in figures $(8,9$ and 10) respectively, we get the following results:

\section{Upper Limit (no Damage)}

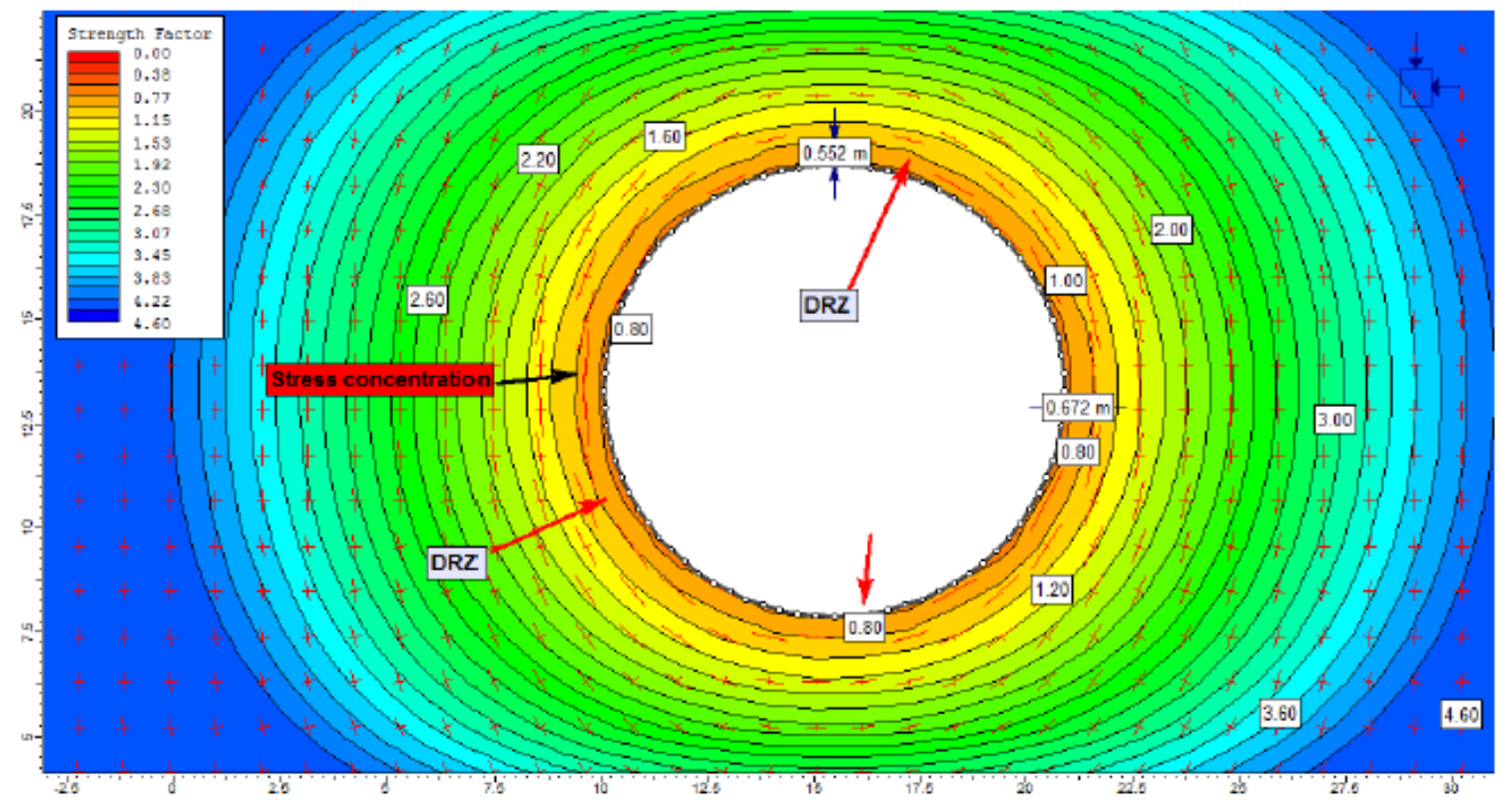

Fig. 8: Analysis of DRZ by Examine2D software at depth $=200 \mathrm{~m}$ and $D=0$. 


\section{Base Case (DRZ)}

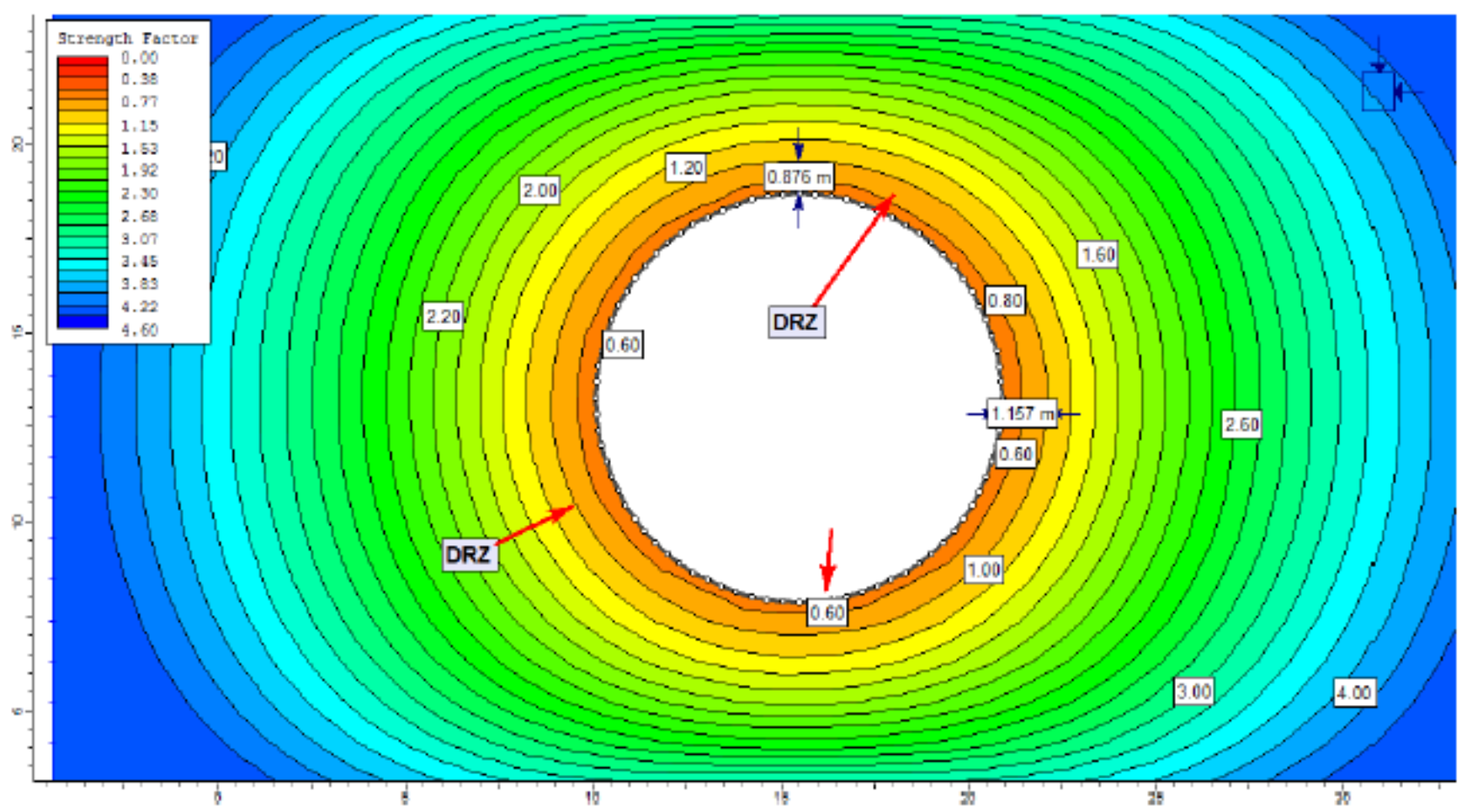

Fig. 9: Analysis of DRZ by Examine2D software at depth $=200 \mathrm{~m}$ and $D=0.5$.

\section{Lower Limit (Heavy Damage or Worst Case)}

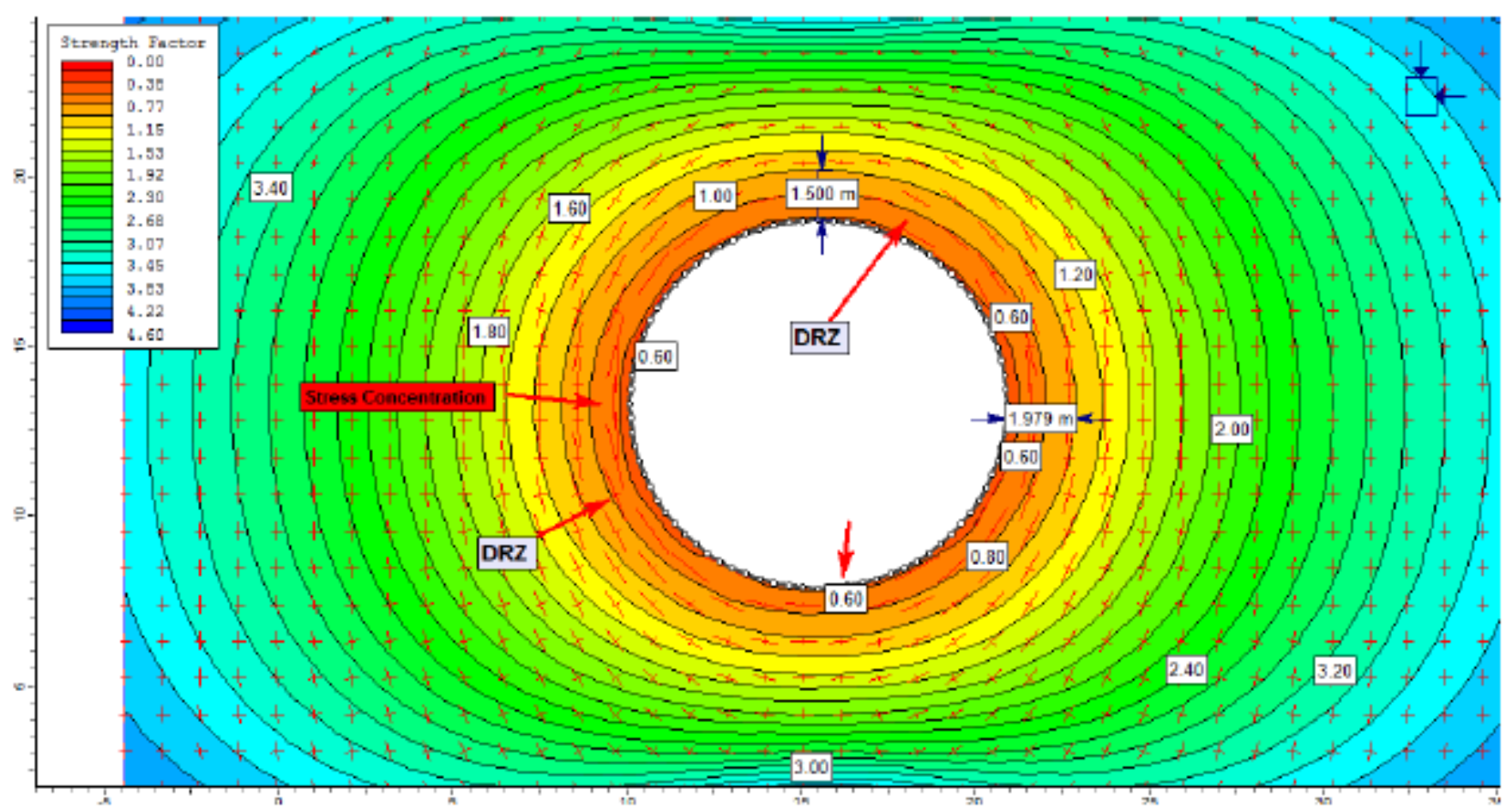

Fig. 10: Analysis of DRZ by Examine2D software at depth $=200 \mathrm{~m}$ and $D=0.8$. 


\subsubsection{DRZ Values at Depth $=400 \mathrm{~m}$}

Similarly, by increasing the excavation depth to $400 \mathrm{~m}$ and $\mathrm{D}=0,0.5$ and 0.8 as shown in figures $(11,12$ and 13) respectively, we get the following results:

\section{Upper Limit (no Damage)}

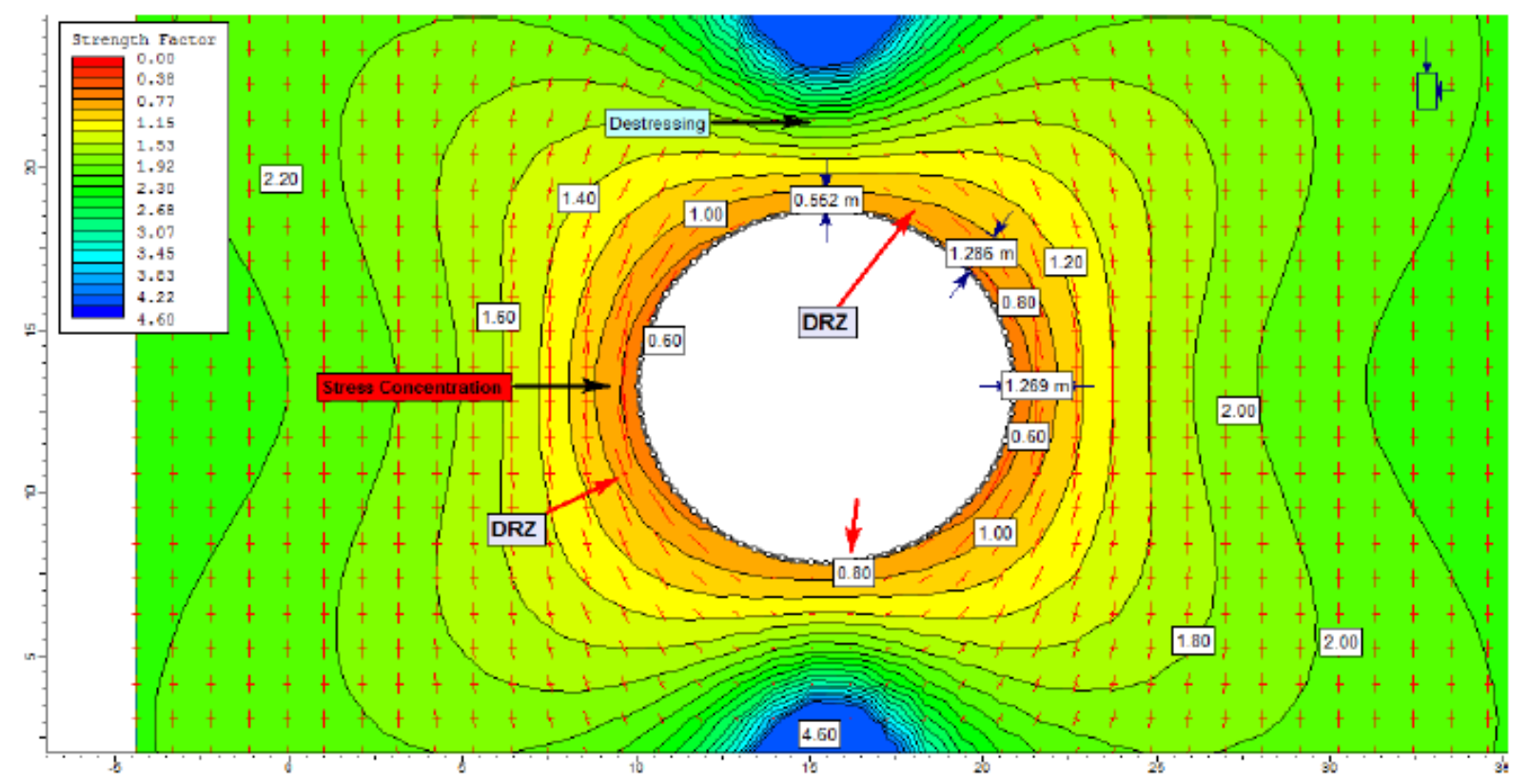

Fig. 11: Analysis of DRZ by Examine2D software at depth $=400 \mathrm{~m}$ and $D=0$.

\section{Base Case (DRZ)}

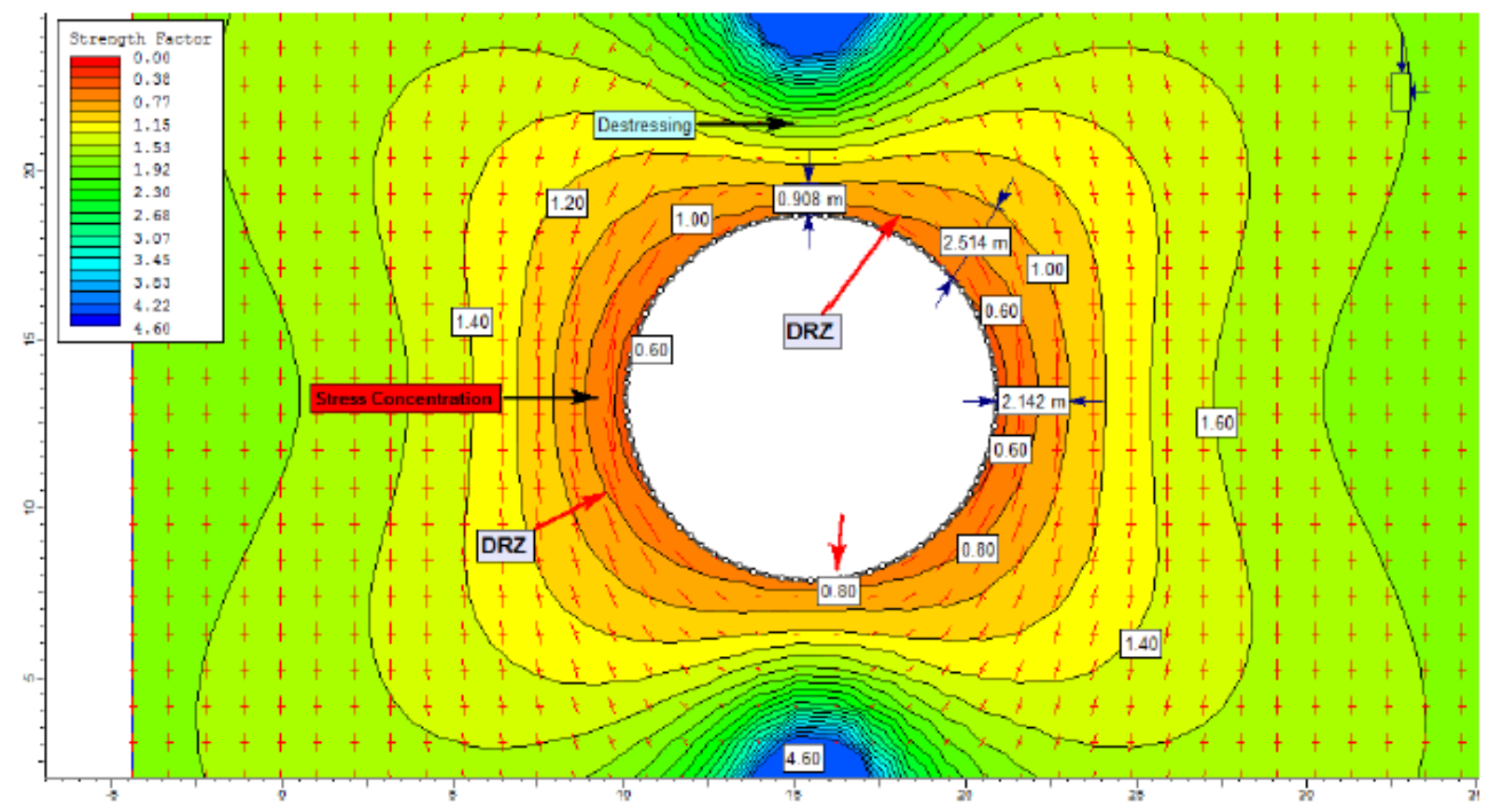

Fig. 12: Analysis of DRZ by Examine2D software at depth $=400 \mathrm{~m}$ and $D=0.5$. 
III. Lower Limit (Heavy Damage or Worst Case)

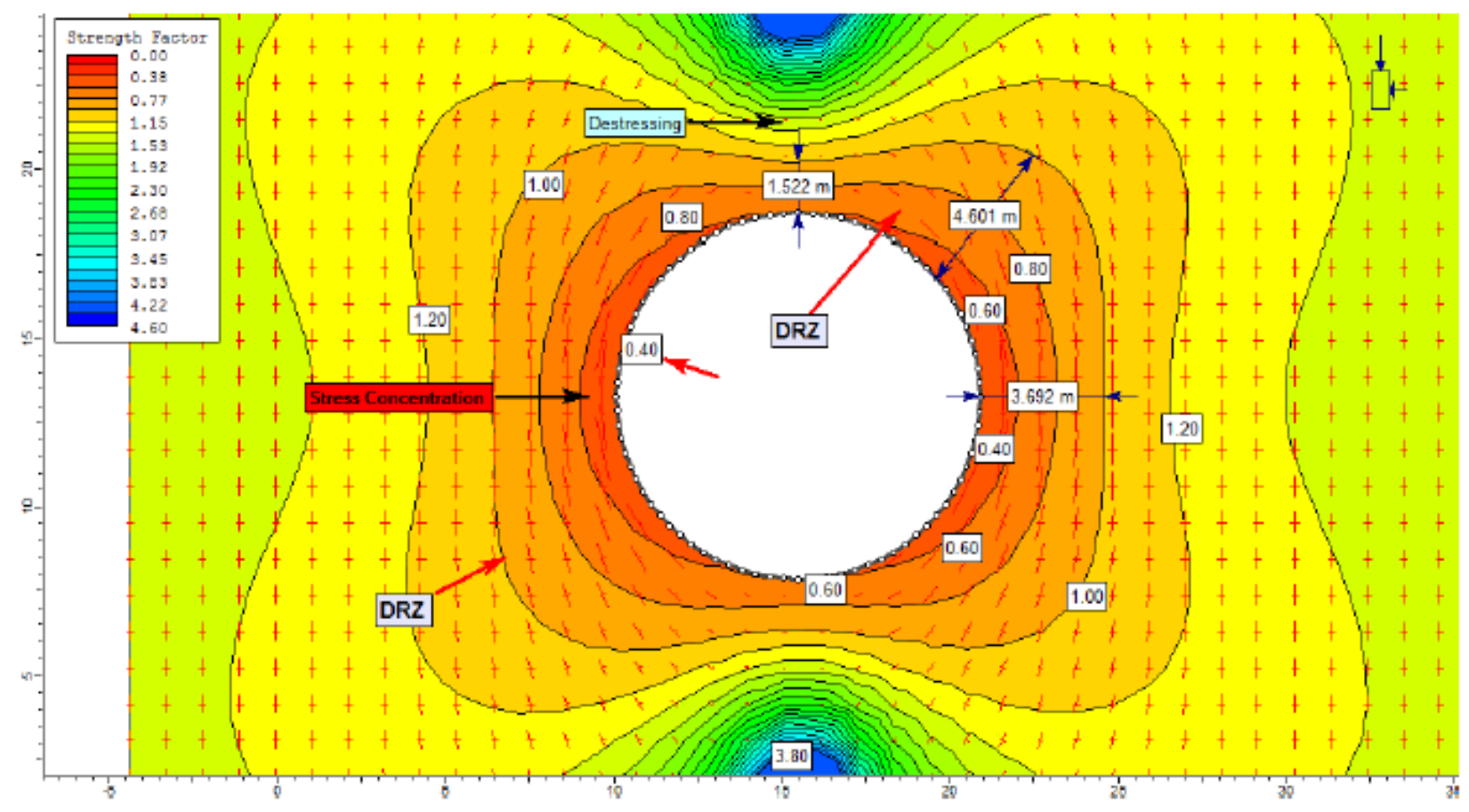

Fig. 13: Analysis of DRZ by Examine2D software at depth $=400 \mathrm{~m}$ and $D=0.8$.

\subsection{Discussion}

From the previous figures, we can define the following results as shown in table 1.

\begin{tabular}{|c|c|c|c|}
\hline $\begin{array}{c}\text { Depth } \\
(\mathbf{m})\end{array}$ & $\begin{array}{c}\text { Disturbance } \\
\text { factor D }\end{array}$ & $\begin{array}{c}\text { DRZ } \\
\text { Thickness }(\mathbf{m})\end{array}$ & $\begin{array}{c}\text { Strength factor } \\
\text { Strength/stress }\end{array}$ \\
\hline \multirow{3}{*}{$\mathbf{1 0 0}$} & 0 & 0.479 & $0.8-1.0$ \\
\cline { 2 - 4 } & 0.5 & 0.843 & 0.8 \\
\cline { 2 - 4 } & 0.8 & 1.393 & 0.6 \\
\hline \multirow{3}{*}{$\mathbf{2 0 0}$} & 0 & 0.672 & 8.0 \\
\cline { 2 - 4 } & 0.5 & 1.157 & 0.7 \\
\cline { 2 - 4 } & 0.8 & 1.979 & $0.5-0.6$ \\
\hline \multirow{3}{*}{400} & 0 & 1.286 & 0.6 \\
\cline { 2 - 4 } & 0.5 & 2.514 & 0.5 \\
\cline { 2 - 4 } & 0.8 & 4.601 & 0.4 \\
\hline
\end{tabular}

\section{At Depth $100 \mathrm{~m}$}

The sandstone is low strength rock, so DRZ values are very markedly. At $(D=0)$, the max. DRZ thickness around the excavation about $(0.479 \mathrm{~m})$. When $(\mathrm{D}=0.5)$, the DRZ thickness increase around the excavation and max. extend to $(0.843 \mathrm{~m})$ at roof and floor due to stresses concentration. When $(\mathrm{D}=0.8)$, as a result of the heavy disturbance occurs, the DRZ thickness increase around the excavation and max. extend to $(1.393 \mathrm{~m})$ at roof and floor due to stresses more concentrated and the strength factor around the excavation boundary ranging from (0.6-1). 


\section{At Depth $200 \mathrm{~m}$}

When increasing the excavation depth, the induced stresses around the excavation increases. So, at $(\mathrm{D}=$ $0)$, the max. DRZ thickness around the excavation about $(0.672 \mathrm{~m})$ at walls due to stresses concentration. When $(\mathrm{D}=0.5)$, the DRZ thickness increase around the excavation and max. extend to $(1.157 \mathrm{~m})$ at walls due to stresses concentration. When $(\mathrm{D}=0.8)$, as a result of the heavy disturbance occurs, the DRZ thickness increase around the excavation and max. extend to $(1.979 \mathrm{~m})$ at walls due to stresses concentration.

\section{At Depth $400 \mathrm{~m}$}

When increasing the excavation depth, the induced stresses around the excavation increases. So, at $(\mathrm{D}=$ $0)$, the max. DRZ thickness around the excavation about $(1.286 \mathrm{~m})$ at walls due to stresses concentration. When $(\mathrm{D}=0.5)$, the DRZ thickness increase around the excavation and max. extend to $(2.514 \mathrm{~m})$ at walls due to stresses concentration. When $(\mathrm{D}=0.8)$, as a result of the heavy disturbance occurs, the DRZ thickness increase around the excavation and max. Extend to $(4.601 \mathrm{~m})$ at walls due to stresses concentration and the strength factor around the excavation boundary ranging to $(0.4)$.

\section{CONCLUSIONS}

From the results, we can summarize the following conclusions:

1- The damaged rock zone (DRZ) around a tunnel boundary has a significant influence on the overall performance of the tunnel.

2- The disturbance, resulting from the excavation method, decreases the compressive strength as well as the deformation modulus.

3- The disturbance resulting from the excavation method used (Drilling and Blasting or Tunnel Boring Machine) has a highly effect on the DRZ thickness due to the reduction in DRZ strength factor.

4- The study showed that the extent of DRZ affected by depth of the excavation. With increasing the excavation depth, the DRZ extent increase.

\section{REFERENCES}

[1] Sato T., T. Kikuchi and K. Sugihara, "In-situ experiments on an excavation disturbed zone induced by mechanical excavation in Neogene sedimentary rock at Tono mine", central Japan. Engineering Geology, 56(1-2): p. 97-108, 2000.

[2] Martino J. B. and C. D. Martin, "Proceedings of the excavation disturbed zone workshop" Canada, 1996.

[3] Martino J. B., "The excavation damaged zone and recent studies at the URL". In: J.B. -Martino (Editor), Proceedings of the 2002 International EDZ Workshop, Toronto, 2003b.

[4] Martino J. B., "The excavation damaged zone- cause and effects". The International EDZ Workshop: Atomic Energy of Canada Limited, 2003.

[5] Bernier F., and C. Davies, "Impact of the excavation disturbed or damaged zone (EDZ) on the performance of radioactive waste geological repositories," in European Commission Report, Luxembourg, 2004.

[6] Tsang C. F, Bernier F. and Davies C., "Geohydromechanical processes in the excavation damaged zone in crystalline rock, rock salt, and indurated and plastic clays - in the context of radioactive waste disposal". International Journal of Rock Mechanics and Mining Sciences, 42(1): 109 -125, 2005. 
[7] Backblom G. "Excavation damage and disturbance in crystalline rock - results from experiments and analyses". SKB Technical Report TR 08-08, SKB Stockholm, 2008.

[8] M. E. Hassan, W.M. Draz, F. A. Ali and S. M. Sleem "Studying the effect of rock type on damaged rock zone around underground excavation" International Journal of Scientific \& Engineering Research IJSER, ISSN 2229-5518, Volume 8, Issue 1, January-2017.

[9] Hoek, E., Carranza -Torres C. T., and Corkum B., "Hoek- Brown failure criterion," Proceedings of the North American Rock Mechanics Society Meeting, Canada, 1-6, 2002.

[10] Hoek E., and Diederichs M., "Empirical estimation of rock mass modulus": International Journal of Rock Mechanics \& Mining Sciences, v. 43, p. 203-215, 2006. 